\title{
Research on the influencing factors of family firm innovation
}

\author{
Liu Yingrui ${ }^{1}$ \\ ${ }^{1}$ School of Business Administration, Zhejiang Gongshang University, Hangzhou, Zhejiang, China
}

\begin{abstract}
Family business plays an important role in the world's economic activities, and has made great contributions to the stability and development of the economy of various countries. Innovation is an important but inexplicable part of the strategic focus of family business. Based on the existing literature, this paper discusses the factors that influence the innovation behavior of enterprises from the perspective of family involvement and external environment.
\end{abstract}

\section{Introduction}

Family enterprises is a kind of ubiquitous enterprise form, which plays an important role in the economic development and progress of various countries. Although compared with family enterprises in developed countries, Chinese family-owned enterprises have a shorter history, but in the past three decades, the number and scale of Chinese family firms have developed rapidly. Especially in the spring of 1992, two years after Deng Xiaoping's talk in the south, the enthusiasm for entrepreneurship nationwide rose, forming a wave of "public entrepreneurship and innovation". At present, after the primitive accumulation of the first generation of leaders, Chinese family businesses have now entered a stage of rapid development and expansion, and their contribution to the national economic development is also increasing. The China's Family Business Development Report (2011) stated that family enterprises accounted for $85.4 \%$ of the total private enterprises in China, and the private economy accounted for more than one-third of China's national economy, especially in the coastal Jiangsu and Zhejiang areas, the proportion is higher. With the development and construction of China's global economic destiny community and export-oriented economy, the operating environment and institutional environment faced by Chinese companies are full of uncertainty and complexity. Thus, innovation has become an effective way and an important means for enterprises to deal with this highly uncertain environment.

The innovation motivation and intensity of domestic family companies are relatively limited. The China's Family Business Health Index Report (2014) Edition pointed out that compared with the average level of Chinese private companies, the intensity of domestic family business's R\&D investment is generally low. Many domestic and foreign scholars have different interpretations about that. Some scholars believe that this is because in family-dominated companies, the family pays too much attention to the non-economic goal of the enterprise, which is social emotional wealth, and shows a tendency to risk aversion, unwilling to make high-risk R\&D investment behavior [1][2]. Some scholars also believe that R\&D investment will weaken the family's control of the enterprise [3], and the managers of the family business want to maintain their control over the enterprise, so they will resist R\&D investment.

\section{Theoretical background}

\subsection{Family business and Family involvement}

\subsubsection{Family Firms}

Definition of Ownership. Family firms occupy an important position in China's private economy. The research on family business must inevitably define the identity of the family business [4]. With the deepening of the research, there are certain differences in the definition of the identity of family firms. Domestic scholars believe that family business is a complex organization formed after the family is involved in the business. The family is embedded in the family business as a social organization, and as the actual controller of the family business, the business owner and the family business should have at least $50 \%$ equity [5]. Later, some scholars also suggested that when the actual controller of a business is a family or a natural person, it is also a family business, which further broadens the definition of family business. Claessens and Fan believe that as long as the family's shareholding ratio reaches $10 \%$, the purpose of controlling the enterprise can be achieved, and it can be regarded as a family enterprise [6]. The proportion of family business ownership in different countries depends on the specific situation. Not only scholars have a different understanding of familyowned business, but also the system and market environment of different countries and regions do as well.

Definition of Management Rights. The management rights of the family enterprise is also a mainstream 
judgment standard in addition to ownership. Being able to participate in the management of the enterprise in terms of management rights often means that the family has a huge influence on the enterprise [7]. The family business must have two or more family members to join the management of the family business, and the professional managers must be closely related to the family [8]. Family members need to have absolute control of the enterprise, and they can ensure their decision-making power and control power by joining the board of directors or senior management team [4].

At this stage, most scholars have started from the perspective of the integration of two powers, requiring family businesses to have both corporate management rights and ownership. In numerous family business literatures [1][9], The criteria for judging a family must meet at least two conditions: 1 . The family should own at least $5 \%$ of the company's shares; 2 . At least two family members in the company should be in the top management team(TMT).

\subsubsection{Family involvement}

Family involvement mainly refers to the fact that family members who actually control the enterprise, participate in the daily management activities of the enterprise. From a certain point of view, this is also an essential difference between them and non-family companies. The dimension of family involvement is mainly divided into four aspects: family ownership, family control, family management and intergenerational inheritance. However, most of the researches on the governance effect of family involvement are based on the involvement of family control, ownership and management rights, and discuss the impact of family involvement on the company's own strategic behavior and related decisions. The family business management structure is an important source of family heterogeneity. From the perspective of management structure, family involvement in different dimensions of heterogeneity has also become an important feature to distinguish family businesses from non-family businesses [10]. There is also a big difference in the research of family involvement and development behavior of family companies.

\subsection{Agency Theory and Social Emotional Wealth Theory}

Agency Theory. In the family business, the special governance structure of the family business shows that the family business must not only deal with the relationship between shareholders and agency managers, but also deal with the contradictions between its own large shareholders and small shareholders. The discussion of agency theory existing in the family includes the agency problems between the managers and the owners, as well as the agency problems among owners: On one hand, family involvement makes the profits of the operators and managers of the enterprise the same, converts the agency costs that may exist in other types of companies into agency advantages, reducing agency costs; On the other hand, family owners control the use of corporate resources for family and individual purposes, and use the convenience of their positions to seek private benefits for the family and themselves; at the same time, exploit small shareholders and sacrifice the interests of small shareholders and companies, so as to benefit their families

Social Emotional Wealth. Gomez-Mejia et al. first mentioned social emotional wealth in 2007. In 2007 to illustrate that the family will pursue non-economic goals for the family's emotional wealth. The theory is rooted in agency theory and corporate behavior theory. The previous research on family business is often not enough to reflect the special mode and behavior essence of family business, and the social emotional wealth theory can explain the special behavior mode of family members. Social and emotional wealth believes that the focus of family-owned enterprises is the family's social and emotional wealth. Saving and increasing social and emotional wealth is the primary reference point for family enterprises to formulate strategies [11]. There are many domestic and foreign researches on the factors that affect the R\&D and innovation of family companies, and it comes down to the dual roles of internal and external factors. Among those, the internal factors mainly include corporate governance structure and social emotional wealth.

\section{Influencing Factors of Innovative Behavior of Family Enterprises}

\subsection{Influencing Factors}

Enterprises invest in R\&D because it is the key to acquiring, enhancing and maintaining their competitiveness [12]. Innovation not only promotes the upgrading of products and processing technologies, but also enables enterprises to absorb the knowledge and technology necessary for successful innovation [13]. Innovation is a shortcut for a company to stand out from the industry and surpass its competitors. Innovation is increasingly important. Research on family enterprises has also been studying the factors that affect the R\&D investment of family enterprises. The influencing factors for enterprise R\&D and innovation can be summarized into two types of internal and external factors by many scholars. The internal factors mainly include corporate governance structure and social emotional wealth, and the external factors mainly include institutional environment, industry environment and corporate social capital.

Family innovation is influenced by many internal factors. Its main applied theories are agency theory and stewardship theory. Previous researches through questionnaire surveys have shown that family ownership is significantly related to corporate strategic control and has a significant impact on corporate innovations [14]. Through researches, domestic scholars such as $\mathrm{Li}$ and $\mathrm{He}$ believe that the excessive concentration of family equity will inhibit innovation [15]. Since social emotional wealth was proposed at a later time, some scholars have combined agency theory and social emotional wealth theory. They take that as tools to believe that the research and development intensity of family companies will change 
with the gap between expectations and performance, especially in family companies that value cross-generation control, R\&D spending will increase [1].

Compared with internal factors, the study of external factors started late, and the system can provide a reasonable explanation for the behavior of certain family companies [16]. Chinese family enterprises in the transition economy are even more unable to circumvent the role of the system. Social capital determines the way in which an enterprise obtains external resources, and the adequacy of social capital is a condition for whether an

Table1. Research on the factors affecting the $R \& D$ and innovation of family enterprises

\begin{tabular}{|c|c|c|}
\hline Influencing factors & Factor breakdown & Representative literature \\
\hline \multirow[t]{3}{*}{ Internal factors } & Management structure & $\begin{array}{l}\text { Wu Yanbing, 2007; Chen and Hsu, 2009; Hsu } \\
\text { and Chang, 2011; Li Jing He Xiaogang, 2012; } \\
\text { Zhou Lixin, 2014; Ashwin et al., 2015; Min } \\
\text { Yijie Chen Zhijun Li Rong, 2016; Luo Hong } \\
\text { Qin Jidong,2019 }\end{array}$ \\
\hline & Enterprise characteristics & $\begin{array}{l}\text { Gudmundson and Tower et al., 2003; Liu Wei } \\
\text { Liu Xing, 2007; Pittino et al., 2009; Munari et } \\
\text { al. 2010; Llach and Nordqvist 2010; Garud et } \\
\text { al,. } 2013\end{array}$ \\
\hline & Social emotional wealth & $\begin{array}{l}\text { Gomez Meijia, 2011; Zhu Hang Ye Qinxue Li } \\
\text { Xinchun, 2012; Miller et al,. 2014; Wu Bingde } \\
\text { Chen Ling, 2014; Dou Junsheng Zhang Lingli } \\
\text { Wang Ning, 2014; Zhu Hang Eric Zhou } \\
\text { Yinghui,2016 }\end{array}$ \\
\hline \multirow[t]{3}{*}{ External factors } & Institutional environment & $\begin{array}{l}\text { Craig and Dibrell, 2006; Zhu Hang Eric et } \\
\text { al., 2016; Yu Shulian, Wang Tengyan, 2016; } \\
\text { Yan Ruosen, Xiao Sha;2018 }\end{array}$ \\
\hline & Industry environment & $\begin{array}{l}\text { Pi Yonghua Bao Gongmin, 2005; Yu Xiaohong } \\
\text { Wang Wei Liang Biming, 2010; Cassia, De } \\
\text { Massis, and Pizzurno, 2011; Wang Lanfang Hu } \\
\text { Yue, 2017; Luo Hong Qin Jidong;2019 }\end{array}$ \\
\hline & Social capital & $\begin{array}{l}\text { Classen et al., 2012; Xu Yanfang Ye Meixiu, } \\
\text { 2014; Zhu Hang Eric et al., 2016; Ren Shuming } \\
\text { Wang Yanling, 2017; Yan Ruosen Xiao Sha, } \\
2018\end{array}$ \\
\hline
\end{tabular}

\subsection{The Influence of Family Involvement in Family Innovation}

Based on social emotional wealth theory, there are different explanations for the impact of family involvement on corporate investment behavior. There are two main aspects: enterprise can conduct $\mathrm{R} \& \mathrm{D}$ and innovation. A big difference between family enterprises and non-family enterprises is the difference in the ownership of social capital between the two. The growth of a family business is a process of continuous integration with the social human capital, social financial capital, social network capital, and social cultural capital that the family business owns [17].

This paper summarizes the factors that affect the innovation of family enterprises, as shown in table 1. 
of family businesses tend to have a more long-term perspective [19]. Because the family business is considered a wealth to be passed on to the next generation, not a contemporary consumer product [20]. Therefore, in order to facilitate the intergenerational inheritance, in order to leave a healthy and prosperous enterprise for the next generation, family managers will be more willing to make a long-term investment.

2. Inhibition theory: Family altruism can also lead to conflicts in goals. Corporate goals conflict with family goals. At this time, family members become "good housekeeper" of the family and the family owner rather than "good housekeeper" of the enterprise [21][22]. These studies suggest that internal conflicts in family enterprises, the desire for family control, and the retention of social and emotional wealth are the main reasons for the low investment in R\&D and innovation. On the other hand, the investment of $R \& D$ by family enterprises often requires a large amount of capital injection and the introduction of related talents, and the injection of funds often means that companies have to raise funds or issue new stocks. That means diluting the ownership of the family, and the introduction of external talents means that the family's management rights are decentralized. At the same time, R\&D investment is often accompanied by a very high failure rate, which is very likely to damage the social and emotional wealth accumulated by the family, including social reputation. Therefore, family enterprises tend to be more averse to investment than non-family enterprises.

\subsection{Relationship between Innovation Environment and Enterprise Innovation Behavior}

The strategic decisions of family companies are not only affected by the internal management structure, but also inevitably by the external environment [23]. The investment behavior of a company is often affected by external macro factors, and the institutional environment can often affect the company's behavior and preferences [16]. The existing literatures about family enterprise generally recognize the important reuse of the innovation environment. A perfect regional innovation environment can provide the necessary financing facilities, innovative technologies and management talents, which are very important in developed markets [24]. A regional innovation environment can help family businesses reduce diversification costs, minimize transaction costs, and alleviate the negative effects of capital market distortions. Meanwhile, it mobilizes management personnel, professional knowledge and technology to form an effective mechanism, so as to increase trust and information within the family and between enterprises, therefore increasing the possibility of sharing risks. Chinese researchers have also used the data of a series of innovation activities of China's family firms to conclude that innovation environment factors will have a positive impact on corporate performance and innovation output. At the same time, they also suggest that regions with better regional innovation environment will also have help to improve the efficiency of innovation across the region.

Therefore, it is crucial to pay attention to external factors and internal factors, the relationship between the two, and how they are affected by the innovation environment.

\section{Conclusions}

This article focuses on the family-owned enterprises, family innovation behavior and related theories. Through combing the definition of family enterprise, it is found that there is no unified definition of family enterprise. It often needs to be defined from the company's own ownership, management rights or intergenerational inheritance, combined with the special background and relevant policies of the research object. At the same time, there are also differences in the research on the impact of family involvement on the R\&D of family business. Previous studies have considered that family involvement has an inhibitory effect on the R\&D of family business, but there are also studies in specific situations (negative performance feedback, family board chairman, etc.), family involvement can promote the R\&D of family businesses. In recent years, some scholars have put forward mutually reconciling views and believe that the influence of family involvement on corporate innovation behavior is inverted U-shaped pattern.

Most of the research on the innovation behavior of family companies is currently concentrated in developed economies. In recent years, research on the innovation behavior of family companies in domestic and developing countries such as Southeast Asia has gradually begun. At present, the research on the innovation behavior of family companies mainly focuses on the theory of social emotional wealth and agency theory. In China's special institutional environment, institutional theory can also be used to interpret family's innovation behaviors. Meanwhile, with the establishment and improvement of the innovation research of the domestic first-generation family enterprise's founder, the research around intergenerational inheritance and second-generation managers also needs further development.

The research significance of this article lies in two aspects: 1. Realistic significance. The importance of innovation in a fierce competitive environment has already been highlighted. The innovation ability of an enterprise is often an important determinant of the market performance of its industry. At the same time, the emergence of family companies in the field of science and technology has increased, and more and more scholars have begun to pay attention to the special attitudes of family companies towards R\&D investment. Most of the existing research focuses on family businesses in more developed countries such as Europe and the United States, and the institutional environment similar to that in developed economies such as Europe and the United States is very different from the institutional environment in developing countries such as Asia, Africa and Latin America. This article summarizes some of the existing influencing factors.

2. Theoretical significance. Research on the innovation theory of family companies has always been the focus. Many scholars at home and abroad are trying to use 
different theories to explain why there is such heterogeneity in the R\&D investment behavior of family companies. From behavioral theory of the firm(BTOF) to agency theory and social emotional wealth theory, in recent years, some scholars have used institutional theory to understand China's special institutional environment and traditional culture, in order to interpret the R\&D behaviors of Chinese family companies. This article mainly starts from agency theory and social emotional wealth theory, understands the factors that affect enterprise innovation, improves theoretical research and provides reference.

\section{REFERENCES}

1. Chrisman, J. J., \& Patel, P. C. Variations in R\&D investments of family and non-family firms: Behavioral agency and myopic loss aversion perspectives. Academy of Management Journal, 2012, 55(4), 976-97.

2. Gómez-Mejía, L. R., Campbell, J. T., Martin, G., Hoskisson, R. E., Makri, M., \& Sirmon, D.G. Socioemotional wealth as a mixed gamble: Revisiting family firm R\&D investments with the behavioral agency model. Entrepreneurship Theory and Practice, 2014, 38(6), 1351-1374.

3. Duran, P., Kammerlander, N., van Essen, M., \& Zellweger, T. Doing more with less: Innovation input and output in family firms. Academy of Management Journal, 2016, 59(4), 1224-1264.

4. Handler, W. C. Methodological Issues and Considerations in Studying Family Businesses[J]. Family Business Review, 1989(3): 257-276.

5. ZHOU Li-xin, HUANG Jie. Corporate Social Responsibility and Performance of Family Business:The Moderating Effect of Internal Capability and External Relationship[J]. Journal of Business Economics, 2012, 1(5):5-15.

6. Claessens, Stijn, Fan, Joseph P. H. Corporate Governance in Asia: A Survey[M] Corporate governance in Asia. Routledge, 2003.

7. Chrisman, J. J. and J. H. Chua, et al. Sources and consequences of distinctive familiness: An introduction[J]. Entrepreneurship: Theory and Practice, 2005(3): 237-247.

8. Daily, C. M., \& Dollinger, M. J. An Empirical Examination of Ownership Structure in Family and Professionally Managed Firms. Family Business Review, 1992, 4, 117-135.

9. Banalieva, E. R., Eddleston, K. A., \& Zellweger, T. M. When do family firms have an advantage in transitioning economies? Toward a dynamic institution-based view. Strategic Management Journal, 2015, 36, 1358-1377.

10. Chua, Chrisman. Sources of Heterogeneity in Family Firms: An Introduction[J]. Entrepreneurship: Theory and Practice. 2012, 36(6): 1103-1113.

11. Gómez-Mejía, L. R., Haynes, K. T., Núñez-Nickel, M., Jacobson, K. J., \& Moyano-Fuentes, J.
Socioemotional wealth and business risks in familycontrolled firms: Evidence from Spanish olive oil mills. Administrative Science Quarterly, 2007, 52(1), 106-137.

12. Porter, M. E. The competitive advantage of nations. Harvard Business Review, 1990, 68(2), 73-93.

13. Lawless, M. W., \& Anderson, P. C. Generational technological change: Effects of innovation and local rivalry on performance. Academy of Management Journal, 1996, 39(5),1185-1217.

14. Hsu, L. and H. Chang. The Role of Behavioral Strategic Controls in Family Firm Innovation[J]. Industry and Innovation, 2011, 18(7): 709-727.

15. Jing Li, Xiao-Gang He. Ownership Intensity and Innovative Performance: A Comparative Analysis between State-Owned and Family-Owned Firms[J]. Journal of Business Economics, 2012, 1(10):40-51.

16. Miller, D. and I. Le Breton-Miller. Deconstructing socioemotional wealth[J]. Entrepreneurship: Theory and Practice, 2014, 38(4): 713-720.

17. Xiao-Ping C, Huai-Zu LI. GROWTH OF FAMILY FIRMS AND MERGE OF SOCIAL CAPITALS[J]. Economic Theory \& Business Management, 2003(06), 45-51.

18. Le Breton-Miller, Miller, D. Agency vs. stewardship in public family firms: A social embeddedness reconciliation[J]. Entrepreneurship: Theory and Practice, 2009, 33(6): 1169-1191.

19. Miller, D., \& Le Breton-Miller, I Family governance and firm performance: Agency, stewardship, and capabilities. Family Business Review, 2006, 19(1), 73-87.

20. Block, J. H. R\&D investments in family and founder firms: An agency perspective. Journal of business venturing, 2012, 27(2), 248-265.

21. Schulze, William S. Lubatkin, Michael H. Dino, Richard N. Toward a theory of agency and altruism in family firms[J]. Journal of Business Venturing. 2003, 18(4): 473-490.

22. Lubatkin, M.H. Schulze, W.S. Ling, Y. Dino, R.N. The effects of parental altruism on the governance of family-managed firms $[\mathrm{J}]$. Journal of Organizational Behavior. 2005, 26(3): 313-330.

23. Jansen, J. J. P., Frams A. J. V. D. B., Volberda H W. Exploratory Innovation, Exploitative Innovation, and Performance: Effects of Organizational Antecedents and Environmental Moderators[J]. Management Science, 2006, 11, 52(11), 1661-1674.

24. Munoz-Bullon F, Sanchez-Bueno M J . The Impact of Family Involvement on the R\&D Intensity of Publicly Traded Firms[J]. Family Business Review, 2011, 24(1):62-70. 